\title{
The Effectiveness of Education Video and Booklet Media for Pregnant Mothers Knowledge on Preparation of Breastfeeding Practice
}

\author{
$1^{\text {st }}$ Dian Puspitasari \\ Midwifery Science Study Program \\ Universitas Jenderal Achmad Yani \\ Yogyakarta \\ Yogyakarta, Indonesia \\ dian.ayaniyka@gmail.com
}

\author{
$2^{\text {nd }}$ Tri Sunarsih \\ Midwifery Science Study Program \\ Universitas Jenderal Achmad Yani \\ Yogyakarta \\ Yogyakarta, Indonesia \\ are_she79@yahoo.com
}

\begin{abstract}
Breastfeeding for new baby borns affects health growth. The preparation of exclussive breastfeeding may begin from pregnancy process therefore good education is required so that mothers will be able to give exclusive breastfeeding well. Education to promote health may be done by video or booklet media. Acknowledging the influence of health education through education video and booklet in knowledge change of pregnant mothers in preparation giving exclusive breastfeeding. The research design that has been used is quasi experiment with two group pre- test and post-test with control with time study approach kohort. This research was done in pregnant mothers class in Jumoyo Village Magelang district Central Java with 32 pregnant mothers respondents divided by action group with video and booklet. This research was done during April to September 2019. Data analyze was using Paired $\mathbf{T}$ Test and Independent $\mathbf{T}$ Test. Results showed there were average differences in knowledge change of pregnant mothers in preparation of giving exclusive breastfeeding on group of education video and booklet media with p-value $<0,005$ and based on the results of great average value both groups, hence it was concluded video media was more effective than the booklet media. Education media plays roles in the success of giving knowledge to society regarding exclusive breastfeeding therefore in this research concluded that education media through video was more effective to improve pregnant mothers' knowledge in giving exclusive breastfeeding.
\end{abstract}

Keywords- Video, Booklet, Exclusive Breastfeeding, Knowledge

\section{INTRODUCTION}

Mother breast milk is an ideal food for baby. Baby that is given optimal breastfeeding shows better intelligence test, inclines to not having overweight or obesity and not fragile against diabetes in later in the future.[1] The range of breastfeeding in Indonesia, although most mothers breastfeed their babies, but only $42 \%$ from babies under 6 months old get exclusive breastfeeding.[2]

One of the efforts to improve the range of exclusive breastfeeding is to promote health. Promoting health is

not only to realize or to improve knowledge of the society regarding health yet also it has effort to facilitate with purpose of society behavior change. The research that was done by Emilia regarding the influence of exclusive breastfeeding counseling towards knowledge and pregnant mothers in Mukim Laure-E Central Simeulue sub-district Simeulue district showed that there was a significant influence between knowledge and mother behavior toward giving exclusive breastfeeding with poster media and leaflet [3]. Health media promotion can be done by several medias and one of them is booklet. Based on research the influence of counseling using booklet media towards knowledge and mother behavior baduta regarding baby and toddler feeding in Kemusu Village Kemusu Sub-District Boyolali District results that booklet media gives influence in improving knowledge and behaviour toward baby and toddler feeding [4].

Based on the description above, the researcher is interested in doing a research with a title " The Effectiveness Of Education Video And Booklet Media For Pregnant Mothers Knowledge On Preparation Of Breastfeeding Practice "

\section{METHOD}

This research is quasi experiment with two group pre-test and post-test with control. The research was done in Public Health Center Salam Area Magelang Central Java Indonesia with samples of 32 pregnant mothers (16 pregnant mothers that are given education video and 16 pregnant mothers are given education booklet). Education is done with amount of 2 times on each group.

Unvariant analysis steps are done by making a frequent distribution from each variable, this analysis result is applied in forms of tables and naration. Bivariant analysis is done to test the relation of the two variables which are free variable and binding variable. Statistic test that is being used is Paired T-Test and Independent T-Test.

\section{RESULT AND DISCUSSION}

\section{A. Result}

Based on table 1 most of respondent characteristics are on healthy reproduction ages which are 20-35 years old 
with amount of 23 respondents (71,9\%). Healthy reproduction ages that is suggested for pregnancy are 20-35 years old because in those ages reproduction organs function optimally. To be viewed from gravida there are 24 respondents $(75,1 \%)$ being pregnant with multi gravida for second pregnancy up to the fourth. To be viewed from education level there are mostly highschool graduate with 20 respondents $(62,5 \%)$. Based of the daily activity most respondents are housewives with 26 respondents $(81,3 \%)$. Most respondents have insurance with amount of 20 respondents $(62,5 \%)$ the insurance types that the respondents have are BPJS and private insurance.

TABLE I. CHARACTERISTIC OF RESPONDENTS BASED ON AGE, GRAVIDA, EDUCATION, ACTIVITY AND INSURANCE OWNERSHIP. (N=32)

\begin{tabular}{|c|c|c|c|c|}
\hline \multirow[t]{2}{*}{ Characteristic } & \multicolumn{2}{|c|}{$\begin{array}{c}\text { Group Video } \\
(n=16)\end{array}$} & \multicolumn{2}{|c|}{$\begin{array}{c}\text { Group Booklet } \\
(n=16)\end{array}$} \\
\hline & f & $\%$ & f & $\%$ \\
\hline \multicolumn{5}{|l|}{ Age } \\
\hline $20-35$ & 9 & 28,1 & 14 & 43,8 \\
\hline$>35$ & 7 & 21,9 & 2 & 6,3 \\
\hline \multicolumn{5}{|l|}{ Gravida } \\
\hline Primi & 2 & 6,3 & 6 & 18,8 \\
\hline Multi & 14 & 43,8 & 10 & 31,3 \\
\hline \multicolumn{5}{|l|}{ Education Level } \\
\hline Elementary Scool & 0 & 0 & 2 & 6,3 \\
\hline Junior Highschool & 4 & 12,5 & 4 & 12,5 \\
\hline Senior Highschool & 12 & 37,5 & 8 & 25 \\
\hline University & 0 & 0 & 2 & 6,3 \\
\hline \multicolumn{5}{|l|}{ Responden Activity } \\
\hline Housewife & 12 & 37,5 & 14 & 43,8 \\
\hline Workers & 4 & 12,5 & 2 & 6,3 \\
\hline \multicolumn{5}{|c|}{ Insurance Ownership } \\
\hline Have None & 7 & 21,9 & 5 & 15,6 \\
\hline ave & 9 & 28,1 & 11 & 34,4 \\
\hline
\end{tabular}

Based on table 2, normality data test is using kolmogorof smirnov with result $p$-value $>0,05$ that research data is distributed normal, therefore the parametrik statistic paired test sample $t$ test and independent sample $\mathrm{T}$ test may be used to do the research data analysis.

TABLE II. NORMALITY DATA TEST

\begin{tabular}{|c|l|c|c|}
\hline No & \multicolumn{1}{|c|}{ Data } & P-value & Conclusion \\
\hline 1 & Pretest Video & 0,2 & normal \\
\hline 2 & Posttes Video & 0,14 & normal \\
\hline 3 & Pretest Booklet & 0,2 & normal \\
\hline 4 & Posttest Booklet & 0,1 & normal \\
\hline
\end{tabular}

Source: Primer Data Year 2019

TABLE III. PAIRED SAMPLES T TeST

\begin{tabular}{|l|c|c|c|}
\hline \multicolumn{1}{|c|}{ Variabel } & Mean Rank & Sig & Description \\
\hline Knowledge & 31,87 & 0,000 & Signifikan \\
\hline $\begin{array}{l}\text { Pre-Post test } \\
\begin{array}{l}\text { Video } \\
\text { Pre-Post test } \\
\text { Booklet }\end{array}\end{array}$ & 30,62 & 0,000 & Signifikan \\
\hline
\end{tabular}

Based on data processing using paired sample $\mathrm{T}$ Test knowledge pre and post with education video earned value sig (2-tailed) / p value amount of 0,000<0,05 therefore may be concluded that there are average result of pregnant mothers knowledge between pretest with postest with using education video. The results difference knowledge pre and post with education using is also earning value sig (2-tailed) / $\mathrm{p}$ value amount $0,000<0,05$ therefore may be concluded that there average difference of knowledge results of pregnant mothers between pretest with postest with education using booklet.

If to be viewed from homogenity test towards the data post test earned significance value based on mean is $0,188>$ 0,05 , therefore may be concluded that varians data post test education video group and booklet are the same or homogen.

TABLE IV. THE DIFFERENCE OF KNOWLEDGE AFTER BEING GIVEN EDUCATION THROUGH VIDEO AND BOOKLET $(\mathrm{N}=32)$

\begin{tabular}{|c|l|c|c|}
\hline \multirow{2}{*}{ No } & \multicolumn{1}{|c|}{ Education Media } & $\begin{array}{c}\text { Mean Post } \\
\text { Test }\end{array}$ & \multirow{2}{*}{ P-value } \\
\cline { 1 - 3 } 1 & Video & 82, & \multirow{2}{*}{0,000} \\
& & 81 & \\
2 & Booklet & 75, & \\
& & 00 & \\
\hline
\end{tabular}

Source: Primer Data Year 2019

Analysis processing result further is using the Independent sample $\mathrm{T}$ test to discover the difference of average knowledge change results of post test with type of data homogen earned data P-value 0,000 which means < 0,005 therefore may be concluded, that there is difference of average result of knowledge change post test by giving education through education videos and booklet. If to be viewed from average result using video media is higher than the booklet mdeia, which is 82,81 which means using video media is more effective than using booklet media to improve pregnant mothers' knowledge regarding preparation of giving the exclusive breastfeeding.

\section{DISCUSSION}

Human knowledge is mostly gained from eyes and ears. Knowledge or cognitive is an important domain in forming one's action (over behaviour) [5]. Knowledge is one of the several things that humans gain through the five senses. Knowledge appears when one is using their five senses to dig materials or certain events that have never seen or felt before [6].

The process of increasing knowledge is inseperable from the health media promotion that is being used. There are promotion medias that are used to increase society's knowledge regarding health. This research is using education health promotion media in video and booklet. One of the effective medias to promote health is video media, which combines audio, visual and animation that have certain messages and expected to have its own attraction or it may be a persuasive message to respondents [7]. Booklet is normally used with a purpose to increase knowledge, because booklet gives specific, and many used as alternative media to study everytime someone is wanting to [8].

According to research regarding the Influence of Health Promotion Media regarding exclusive breastfeeding towards Increasing Mothers' Knowledge in the working area of Public Health Center Lubuk Begalung Padang Tahun 2014, found that the results of Health Promotion using film media 
was more effective in increasing knowledge compared to using leaflet media [9]. This research matched the research result which video media, since its audio and visual, was more effective to give an understanding of knowledge to the respondents than the booklet media.

The benefits from the health promotion media in video form are: (1) Well-known by society ; (2) Involving all the five senses. ; (3) Easier to understand ; (4) More attractive because there are sounds and moving images; (5) Interface; (6) The application can be controlled; (7) The range is relatively wider ; (8) As an education tool and can be repeated [7].

Based on the research of Effectiveness of Health Education Through Multimedia and Interface Towards the Knowledge and Pregnant Mothers Behaviour Regarding Breastmilk and Breastfeeding may be concluded that the health education through multimedia can be applied in the health service area particularly in basic health service such as at Public Health Center (PHC), because PHC is the health provider that has important roles in mothers and children health especially in the success of breastfeeding for 2 first years of a child's age. Increasing knowledge can be earned in this research, either the one that is delivered by multimedia methods or interface, it gives certain meaning that both methods are equally increase knowledge. However, the health education using multimedia method, has the ability in increasing knowledge and behaviour higher than the interface method.[10]

\section{CONCLUSION}

Based on the research and discussion in this research can be concluded that the education video and booklet media both can increase knowledge for pregnant mothers in the preparation of giving exclusive breastfeeding. Yet, the effectiveness from both education media can be viewed from the average results of increasing knowledge, proving that video media has the increasing rates higher than the media booklet, therefore it can be concluded that video media is more effective to increase knowledge than the booklet media.

\section{REFERENCES}

[1] S. H. Suffian, F. Rumianti, and E. Sumbayak, "Pengaruh Air Susu Ibu Eksklusif terhadap Perkembangan Kognitif dan Perilaku Anak Usia 624 Bulan di Puskesmas Kecamatan Grogol Petamburan pada Tahun 2016," vol. 23, no. 64, pp. 15-21, 2016.

[2] K. P. Karana and Kate Rose, "Jutaan bayi di Indonesia kehilangan awal terbaik dalam hidup mereka," 2016.

[3] R. C. Emilia, "Pengaruh Penyuluhan Asi Eksklusif Terhadap Pengetahuan Dan Sikap Ibu Hamil Di Mukim Laure-E Kecamatan Simeulue Tengah Kabupaten Simeulue (NAD) Tahun 2008," 2009.

[4] L. Liestyawati, "Pengaruh Penyuluhan Dengan Media Booklet Terhadap Pengetahuan Dan Sikap Ibu Baduta tentang Pemberian Makan Bayi dan Anak (PMBA) di Desa Kumusu Kecamatan Kumusu Kabupaten Boyolali," 2018

[5] S. Notoatmojo, Kesehatan masyarakat: Ilmu dan seni. Jakarta: Rineka Cipta, 2011

[6] S. Notoatmodjo, Promosi Kesehatan Dan Perilaku Kesehatan. Jakarta: Rineka Cipta, 2012

[7] E. D. dkk. Larasati, "Efektivitas penggunaan media promosi kesehatan video yoga dalam meningkatkan motivasi kesehatan wanita usia subur tentang kesehatan reproduksinya," J. Keperawatan, vol. 6, no. 2, pp. 88-101, 2015.

[8] M. Wena, Strategi pembelajaran inovatif kontemporer suatu tinjauan konseptual operasional. Jakarta: Bumi Aksara, 2009.

[9] B. Suhertusi, Desmiwarti, and E. Nurjasmi, "Pengaruh Media Promosi Kesehatan tentang ASI Eksklusif terhadap Peningkatan Pengetahuan Ibu di Wilayah Kerja Puskesmas Lubuk Begalung Padang Tahun 2014," J. Kesehat. Andalas, vol. 4, no. 1, pp. 17-22, 2015.

[10] P. Harpita and R. Padmawati, "Efektifitas Pendidikan Keswhatan Melalui Multimedia dan Tatap Muka terhadap Pengetahuan dan Sikap Ibu Hamil tentang ASI dan Menyusui,” J. Care, vol. 5, no. 2, pp. 156167, 2017. 